DIW BERLIN

Discussion

Papers

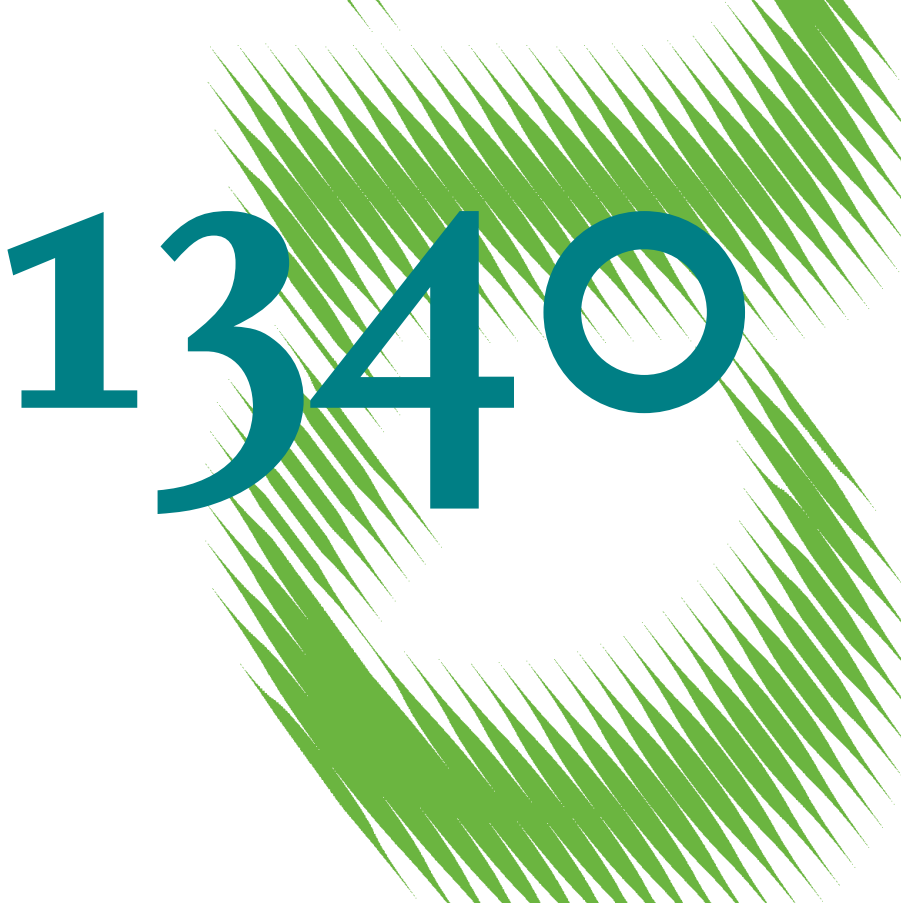

German MPs' Outside Jobs and Their Repercussions on Parliamentary Effort 
Opinions expressed in this paper are those of the author(s) and do not necessarily reflect views of the institute.

IMPRESSUM

(C) DIW Berlin, 2013

DIW Berlin

German Institute for Economic Research

Mohrenstr. 58

10117 Berlin

Tel. $+49(30) 89789-0$

Fax +49 (30) $89789-200$

http://www.diw.de

ISSN print edition $1433-0210$

ISSN electronic edition 1619-4535

Papers can be downloaded free of charge from the DIW Berlin website:

http://www.diw.de/discussionpapers

Discussion Papers of DIW Berlin are indexed in RePEc and SSRN:

http://ideas.repec.org/s/diw/diwwpp.html

http://www.ssrn.com/link/DIW-Berlin-German-Inst-Econ-Res.html 


\title{
German MPs' outside jobs and their repercussions on parliamentary effort
}

\author{
Felix Arnold*
}

This version: December 2, 2013

\begin{abstract}
It is a longstanding debate whether members of parliament (MPs) should be allowed to follow sideline jobs in addition to their mandate. Critics claim that politicians already face binding time constraints and that moonlighting might lead to a neglect of inner-parliamentary duties. The purpose of this study is therefore to investigate whether politicians with more sideline jobs show less effort inside parliament. To address this question, I collected novel data on German members of parliament from 2009-2013. Using a selection on observables approach that controls for legislator ability, I find that higher outside earnings are associated with a significantly lower attendance rate as well as fewer speeches, oral contributions, interpellations and group initiatives. These results are robust to a variety of tests. My findings suggest that time caps on moonlighting along with stricter disclosure rules for outside activities might be necessary.
\end{abstract}

$\begin{array}{ll}\text { Keywords: } & \text { Outside Earnings, Parliamentary Effort, } \\ & \text { Moonlighting Politicians, German Bundestag }\end{array}$

JEL classification: D72, D73, J22

*BDPEMS, Free University Berlin and DIW Berlin. Contact: farnold@diw.de, DIW Berlin, Mohrenstrasse 58, G-10117 Berlin, Tel.: +49 3089789 166. I want to thank Ronny Freier, Alexandra Avdeenko, Thorsten Martin, Johannes Geibel, Sebastian Schmitz and Benedikt Meyer-Bretschneider for their helpful comments. I am also indebted to Martin Brümmer and Andrea Gertig-Hadaschik for providing me access to their data. Finally, my thanks go to Peer Steinbrück who gave me the idea for this research project. 


\section{Introduction}

Members of parliament ${ }^{1}$ (MPs) nowadays lead a very transparent life. Citizens demand accountability, and new disclosure rules regarding activities outside parliament allow them to judge how legislators interpret their mandate. For example, German politician Peer Steinbrück (social democrats) faced public pressure after the press revealed that he accumulated non-negligible outside earnings with speeches at corporate events while at the same time missing important votes in parliament. ${ }^{2}$ When he ran as candidate for chancellor in the 2013 federal election against the incumbent Angela Merkel (conservatives), commentators agreed that his many sideline jobs were one of the reasons for his defeat.

But why should citizens punish excessive moonlighting by politicians? There are two possible explanations. First, outside interests might cast doubt on independent decision making in the assembly. According to this "conflict of interest" view, citizens punish MPs because they think that influence in parliament can be bought. Second, electoral punishment also makes sense if sideline activities lead of a neglect of inner-parliamentary duties. Citizens have a right to complain when their MP shirks in parliament to follow lucrative sideline jobs; after all they are paying him via tax money. As the principal, citizens want to know whether their elected agent shows the necessary commitment to execute his job as a representative of the people. Therefore, it is interesting to know whether the amount of MPs' outside activities has any negative effect on inner-parliamentary effort. This is the topic I am concerned with in this paper.

Using novel data on the individual level of German MPs from the $17^{\text {th }}$ Bundestag (2009-2013), I find that higher outside earnings are associated with significantly lower attendance rates in parliament, as well as fewer speeches,

\footnotetext{
${ }^{1}$ I use the words member of parliament, MP, delegate, representative, member of the Bundestag, legislator, deputy and politician interchangeably in this article.

${ }^{2}$ http://www.spiegel.de/politik/deutschland/ex-minister-steinbrueckparlamentsschwaenzer-mit-spitzenverdienst-a-712225.html, accessed on November $15^{\text {th }}$, 2013.
} 
oral contributions, interpellations and group initiatives. For example, a one standard deviation increase in outside earnings is associated with a decrease of three percentage points in the attendance rate or 4.22 fewer speeches per legislative term, which corresponds to one third or respectively one fifth of a standard deviation in these variables. The results are robust to the inclusion of a wide range of covariates and individual characteristics, including proxies for legislator ability. Additionally, they also hold for important subgroups of the Bundestag population. Furthermore, the method of calculation of outside income does not affect the qualitative results.

I contribute to the literature in three ways. First, evidence on the interplay between outside earnings and activity in parliament is scarce and does not exist for the case of Germany at all. Second, I use additional measures of parliamentary effort that have not been looked at so far. My findings therefore validate and complement other studies (Bernecker, 2013; Besley and Larcinese, 2011; Fisman, Harmon, Kamenica, and Munk, 2012; Gagliarducci, Nannicini, and Naticchioni, 2010) that exclusively employ attendance rates to proxy for shirking in parliament. Third, I introduce new measures that allow me to control for unobserved legislator ability by making use of special institutional features of the German electoral system.

The remainder of this paper is structured as follows. First, I review the literature on politicians' outside earnings in Section 2. Then, Section 3 describes the institutional setting in Germany and introduces the reader to the disclosure rules that allow me to calculate what MPs earned besides their mandate during the term of the $17^{\text {th }}$ Bundestag. In Section 4, I shortly describe my dataset while Section 5 makes the reader familiar with the empirical strategy used in this paper. Results of my empirical analysis can be found in Section 6. Some robustness checks are provided in Section 7. Finally, Section 8 concludes. 


\section{Literature}

The empirical literature on politicians' activities outside parliament has developed only recently along with the availability of data and new transparency rules requiring disclosure of all ancillary activities by active MPs. I will shortly review the empirical evidence from Italy, the UK, and mostly, Germany.

Looking at Italian MPs, Gagliarducci, Nannicini, and Naticchioni (2010) claim that there exists a tradeoff between the quality of elected officials and the time they devote to political life. According to this argument, prohibiting outside activities would lead to adverse selection where the most able citizens do not run for office anymore because they would suffer severe income losses. Having data on pre-election income of Italian MPs from 1996 to 2006, they find that politicians who used to be successful in the market show less effort in parliament once they are elected. According to the authors, society could thus choose between bad but dedicated or good but shirking politicians. ${ }^{3}$

For the UK House of Commons, it has been investigated whether MPs' outside interests follow election cycles (Geys, 2013). If these activities are seen critically by the public, they should decrease prior to elections to preserve chances of winning. The author observes that especially MPs that run for reelection in highly competitive districts adjust their outside interests in the expected direction prior to election date.

In Germany, disclosure rules for politicians' outside earnings have been in place since July 5th, 2007. This triggered an empirical literature which was mostly descriptive in nature. Mause (2009) finds that members of the right wing parties in the Bundestag (CDU/CSU and FDP) follow significantly more side activities than their colleagues from other (left-wing) parties. It does not seem to play a role, however, if a delegate was directly elected or got into the assembly via his party list. ${ }^{4}$ Furthermore, MPs who have

\footnotetext{
${ }^{3}$ For a model of good and bad politicians, see Jennings (2011).

${ }^{4}$ Germany has a mixed-member electoral system where half of all representatives are elected in a single-seat district system while the other half comes from a proportional
} 
served more terms are also more active outside parliamentary life. Probably, some time in parliament is necessary to establish ties and foster contacts to employers outside the assembly. Geys and Mause (2012a) ask the question whether female legislators are different to their male counterparts with respect to outside jobs. While women in the Bundestag have fewer outside employments in general, the authors point to a critical mediating role of the family situation: More children increase men's outside activities, but have no effect for women. Furthermore, "young mothers" seem to refrain from moonlighting.

Niessen and Ruenzi (2010) take a closer look at the outside employers of German legislators and compare firms with political connections to firms that lack these ties. In line with the cross-country literature on political connections (see for example Faccio (2006)), they find that firms with Bundestag members on their payroll deliver a better performance, for example in terms of return on equity or return on investment. ${ }^{5}$ This analysis is based on financial market data from the years 2006 and 2007. However, it is hard to tell whether politicians help firms to perform better or whether politicians manage to self-select only into firms that perform above average.

Becker, Peichl, and Rincke (2009) test whether the degree of electoral competition plays a role in the determination of outside earnings using an instrumental variable approach. For directly elected candidates of the German Bundestag, they find that an increase in the individual-specific vote margin $^{6}$ in the previous election is associated with significantly higher outside earnings. Hence, politicians that lack real competition can more easily shirk in parliament and follow profitable sideline activities.

To the best of my knowledge, there has been no work on the German Bundestag so far that links outside earnings to activity inside parliament. With representation system. For details, see Section 3.

${ }^{5}$ Politics can also influence firms through more indirect channels. For example, Bank, Cheffins, and Goergen (2009) link dividend payments to the political orientation to the party in power.

6 "Vote margin" is hereby defined as own first votes minus first votes of the runner-up. 
this paper, I shall try to close this gap. While Gagliarducci, Nannicini, and Naticchioni (2010) look only at the effect of outside earnings on absenteeism for Italian MPs, I also collected measures of in-house productivity like speeches held, oral contributions, interpellations and group initiatives that can be used as additional outcome variables of interest. These measures have not been looked at so far. ${ }^{7}$ Of course, quantitative performance indicators have problems and can be manipulated, as Geys and Mause (2013) note. For example, a delegate can put his name on an inquiry to the government while the actual work is completely done by his staff. I am aware of these caveats. Nevertheless, I address another issue raised by Geys and Mause (2013), namely the challenge to explore and to control for productivity differences among MPs that influence both activity inside and outside parliament. I will elaborate below how I proxy individual-specific differences in productivity.

\section{$3 \quad$ Institutional Setting}

The Bundestag is the lower house in Germany's bicameral legislature and elections take place every four years. The mixed-member electoral system consists of two tiers: A majoritarian tier and a proportional tier. ${ }^{8}$ Consequently, each German citizen has two votes at the federal election: The first vote serves to directly elect a candidate from one's district by majority rule. The second vote is given to a party; and seats are allocated proportionally according to the vote shares achieved. Note that almost all candidates run in both tiers: While being associated to their "home" constituency, they also

\footnotetext{
${ }^{7}$ An important exception are Mocan and Altindag (2013), who are interested in the work effort of members of the European Parliament follwing a deputy salary harmonization reform in 2009. However, their paper differs from mine as their main explanatory variable is not outside earnings, but remuneration for inner-parliamentary activity. Also, their main outcome variable is attendance during roll-call votes and other parliamentary activity variables are used only as an aside. They find that an increase in salaries decreases attendance. Interestingly, Fisman, Harmon, Kamenica, and Munk (2012) do not find this effect using the same reform.

${ }^{8}$ The German electoral system is an effort to combine majoritarian and proportional elements in an efficient way. See Piolatto (2011) for a study of advantages and drawbacks of both rules.
} 
appear somewhere on the party list. ${ }^{9}$

Half of all MPs are elected via first votes, while the other half is indirectly elected via second votes. Which candidate makes it into the assembly in the second (proportional) tier depends on his or her position on the party list which is arranged on the state level prior to the election. ${ }^{10}$ At least five percent of second votes have to be attained in order to be represented with a parliamentary group in the assembly. In the $17^{\text {th }}$ German Bundestag (2009-2013), five parties met this criterion: CDU/CSU (conservative, 239 seats), SPD (social-democratic, 146 seats), FDP (liberal, 93 seats), GRUENE (green/environmental, 68 seats) and DIE LINKE (leftist, 76 seats). The overall size of the assembly was hence $622{ }^{11}$

According to the rules of conduct for members of the German Bundestag ${ }^{12}$, all delegates are required to disclose their paid activities besides their mandate. Failure to do so can result in a substantial fine of half an MPs yearly earnings. In this study, I want to make use of these self-reported earnings. However, the German disclosure rules do not make it possible to calculate the exact amount representatives earn with their outside jobs. In fact, payment for these activities has to be reported in three categories only: Level 1 (1000 to 3500 Euro), Level 2 (3500 to 7000 Euro) and Level 3 (more than 7000 Euro). Additionally, deputies have to indicate the frequency of these income streams (monthly, yearly or one-time) and disclose their sponsor/employer. Outside incomes under 1000 Euro per month or 10000 Euro per year do not have to be reported at all.

\footnotetext{
${ }^{9} \mathrm{~A}$ good position on the party list thus serves as an alternative way to get into the assembly if the district is lost.

${ }^{10}$ The size of the Bundestag is at least 598 seats. It can become larger due to so-called overhang mandates (Überhangmandate). Parties can keep seats which were directly won even if their vote share determined by second votes is too small for the resulting overall number of seats.

${ }^{11}$ Note that later on in the empirical analysis, my number of observations is $652>622$. When some delegates drop out during the legislative term due to death, illness or professional reorientation, they are replaced by candidates which are next up on the party list, such that the total number of people who have - at least for some time - been a member of the $17^{\text {th }}$ Bundestag is 652 .

${ }^{12}$ http://www.bundestag.de/bundestag/aufgaben/rechtsgrundlagen/go_btg/anlage1.html, accessed on November $15^{\text {th }}, 2013$
} 
This gives members of the Bundestag some leeway in hiding income information from the public, as Geys and Mause (2012b) note. Especially the highest category (Level 3) seems problematic. Citizens can not tell whether a third category income was 7000, 15000 or 50000 Euro. Furthermore, payments of up to 11999 Euro per year remain unseen if they are evenly split over the months and hence fall into the no-reporting category of under 1000 Euro per month. If MPs have some means to manipulate the size of their sideline income (for example if they are self-employed as a lawyer), they could game the system and hide substantial parts of their earnings by generating incomes just at the top end of categories 1 or 2 . Hence, when I calculate the outside earnings of German MPs, I likely have some measurement error.

In order not to make any false accusations and in line with the principle of conservatism, I will take the lowest possible number in each category to calculate MPs' outside earnings. Hence, a reported Level 2 income, monthly, will be counted as $3500 \cdot 12=42000$ Euro per year. In the same vein, a yearly Level 3 income will be counted as exactly 7000 Euro. In the end, I summarize all earnings for each delegate that accrue over the sample period, namely the legislative term of the $17^{\text {th }}$ German Bundestag from 2009/09 to $2013 / 09{ }^{13}$

\section{Data}

I collected data on the activities of the members of parliament of the $17^{\text {th }}$ German Bundestag covering the years from 2009 to 2013. These are crosssectional data on the level of the individual deputy, giving me 652 observations in total. These data stem from different sources. Activity in parliament has been analyzed by journalists of the weekly newspaper "Die Zeit" and they

\footnotetext{
${ }^{13}$ If I calculate the global sum of outside earnings of all MPs over the whole legislative term in my dataset, I find that this number is just above 31 million Euro. This nicely validates the estimate of Hönigsberger (2013), who finds that all German moonlighting representatives together earned about 32 million Euro during the term using slightly less conservative assumptions. As he notes, this non-negligible amount corresponds to the term budget of a small parliamentary group like the FDP.
} 
have made the dataset available for download on their data blog. ${ }^{14}$ Representatives are required to disclose their activities outside parliament on the website of the Bundestag. I collected these data from the individual webpages each representative has. A crawler was used to read out and store the individually reported side activities. ${ }^{15}$ Data on roll call vote attendance can be found on the transparency portal abgeordnetenwatch.de. I got information on number of children, number of terms served and marital status from the NDV GmbH, a firm publishing the "Handbook German Bundestag" in regular intervals. ${ }^{16}$ Finally, information on occupation, year of birth, gender and party affiliation of the candidates can be obtained from the Federal Statistical Office. ${ }^{17}$

Table 1 gives summary statistics of the variables in my dataset. One can see that there is substantial heterogeneity among MPs with respect to activity inside as well as outside parliament. Most variables that measure in-house productivity (Panel 1) display a feature referred to in the literature as overdispersion: Their variance is greater than their mean. This happens when most MPs have relatively few activities and some MPs display lots of activity. This special data structure will make the use of non-standard regression techniques necessary - as explained in Section 5. The interested reader can find a histogram of all parliamentary activity variables in Figure 1 in the appendix. Of all 652 representatives that used to be a member of the $17^{\text {th }}$ Bundestag, only 214 reported positive outside earnings. Among these 214 deputies, the mean minimum income from ancillary activites was roughly 145000 Euro during the legislative term (not shown here). Note that

\footnotetext{
${ }^{14}$ The interested reader can download the data under http://blog.zeit.de/opendata/2013/07/25/155-965-datensatze-fur-unsere-abgeordnetenbilanz/, accessed on November $18^{\text {th }}, 2013$.

${ }^{15}$ I thank Martin Brümmer for writing the extraction algorithm and providing me with the data. The date of extraction is September $25^{\text {th }} 2013$ and hence just after the federal election for the $18^{\text {th }}$ Bundestag, implying that I have all outside activities of members of the $17^{\text {th }}$ Bundestag in my data.

${ }^{16}$ I thank Andrea Gertig-Hadaschik for sending me the data.

${ }^{17}$ I used a string-based matching algorithm to merge all these different datasets on the level of the individual legislator. Numerous cross checks and manual reviewing of critical matches were used to ensure the accuracy of the merged data.
} 
calculating this average over all MPs - also the ones which report zero outside earnings - reduces this number to 47580 Euro, as indicated in Table 1. The MP with the highest outside income (Michael Glos of the CSU) earned 752000 Euro over the legislative term - according to the most conservative estimate. Bundestag members are on average 51 years old and about one third of them are female. The government coalition comprises a bit more than half of all representatives and is hence minimum winning. Two thirds of all MPs are married. The average MP has 1.55 children and has been in the Bundestag for 2.81 terms.

\section{$5 \quad$ Empirical Strategy}

I shall employ a multiple regression approach to estimate the effect of outside activities on inner-parliamentary effort. Therefore, I propose the following empirical model:

$$
Y_{i}=\alpha+\beta \cdot \text { OutsideEarnings } s_{i}+X_{i}^{\prime} \gamma+\epsilon_{i}
$$

I have a measure of deputy "productivity" on the left hand side of my empirical model. This variable $Y_{i}$ will be attendance at roll call votes, speeches held, oral contributions during debate, the frequency of minor interpellations or the number of group initiatives a delegate is part of. Note that all these measures (except for attendance) are count variables greater than zero and have a highly skewed distribution (see also Table 1 above and Figure 1 in the appendix). Hence, an ordinary least squares estimation seems inappropriate. Having only positive count data here, a Poisson model could be estimated. However, all dependent variables I want to use are overdispersed - their variance is greater than their mean. Consequently, a negative binomial regression, estimated via maximum likelihood, is the first choice since it does not restrict mean and variance to be equal like the Poisson model (see also Long and Freese (2006)). For attendance, I employ a right censored tobit model to account for the fact that the attendance rate cannot exceed 100 percent. On the right hand side, I need to quantify how extensively rep- 
Table 1: Descriptive Statistics for all MPs

\begin{tabular}{|c|c|c|c|c|c|}
\hline Variable & Mean & Std. Dev. & Min. & Max. & $\mathrm{N}$ \\
\hline \multicolumn{6}{|c|}{ Panel 1: Outcome Variables } \\
\hline Attendance & 91.77 & 9.71 & 41.9 & 100 & 612 \\
\hline Speeches & 29.57 & 20.66 & 0 & 140 & 652 \\
\hline Oral Contributions & 9.41 & 11.93 & 0 & 136 & 652 \\
\hline Interpellations & 89.92 & 143.78 & 0 & 957 & 652 \\
\hline Group Initiatives & 81.12 & 98.10 & 0 & 516 & 652 \\
\hline \multicolumn{6}{|c|}{ Panel 2: Explanatory Variables } \\
\hline Indicator Outside Earnings & 0.33 & 0.47 & 0 & 1 & 652 \\
\hline Outside Earnings $(€)$ & 47580.17 & 111156.16 & 0 & 752484 & 652 \\
\hline \multicolumn{6}{|c|}{ Panel 3: Control Variables } \\
\hline Number of Terms & 2.81 & 1.89 & 1 & 11 & 620 \\
\hline Number of Children & 1.55 & 1.39 & 0 & 7 & 620 \\
\hline Age & 51.44 & 10.1 & 25 & 76 & 652 \\
\hline Female & 0.33 & 0.47 & 0 & 1 & 652 \\
\hline Government Coalition & 0.53 & 0.5 & 0 & 1 & 652 \\
\hline Married & 0.64 & 0.48 & 0 & 1 & 652 \\
\hline Directly Elected & 0.48 & 0.5 & 0 & 1 & 612 \\
\hline Position on Party List & 9.07 & 11.69 & 1 & 69 & 538 \\
\hline Excess Votes & 0.24 & 1.13 & -5 & 9.45 & 604 \\
\hline
\end{tabular}

resentatives followed side activities. Therefore, I take the minimal amount of money deputies must have earned according to what they declare on the website of the Bundestag. Under the assumption that the labor market is efficient, people with higher outside income must have devoted more time and energy to moonlighting, ceteris paribus. Note that I take the most conservative - that is, the lowest - estimate of ancillary income. My hypothesis is that, ceteris paribus, outside activities harm inner-parliamentary effort, such that I expect $\beta<0$. 
A great challenge when estimating whether side activities and parliamentary duties are substitutes or complements is to control for potential confounding variables. In theory, one can imagine both the 'substitutes' and the 'complements' hypothesis to be true. Most people would expect that inside and outside activities are substitutes. This implies that MPs with higher ancillary income contribute less to parliamentary life, due to simple time constraints. If you keep up your practice as a lawyer and meet with clients, you cannot simultaneously stand at the speaker's desk in the Bundestag. Therefore, one would expect the correlation between moonlighting and parliamentary activity to be negative.

However, one could also conjecture that there is a third variable, like individual ability, skill or smartness, that drives both activity inside and outside parliament. Some deputies might just be more productive than others, hence generating large amounts of ancillary income while being an active and dutiful member of parliament at the same time. If the empirical model did not control for these productivity differences, one would underestimate (in absolute terms) the negative effect of outside interests on parliamentary duties.

Hence, I need a measure that controls for individual specific skills capturing productivity differences between members of parliament. Fortunately, I have information on the party list position on basis of which each MP has been elected into the assembly. Why should this be a signal of individual productivity? The underlying assumption here is that parties care for a high vote share in the election. Since they are most likely to reach this goal when they nominate their best men and women as candidates, one can reasonably conclude that the position on the party list reflects individual skills that are unobserved by the researcher but known to the party that designs the list. I can hence use the position on the list as a proxy for individual skill. ${ }^{18}$

\footnotetext{
${ }^{18}$ Strictly speaking, this argument only holds for half of all MPs, namely for the ones that got elected into the assembly via the party list. Nevertheless, a party also has incentives to place good direct candidates high on the list to provide them an outside option if they do not get a majority in their constituency. Hence, I also expect the party list proxy to work for directly elected candidates that come from marginal (highly contested) districts. The only group where the proxy fails is for direct candidates in safe districts. In the robustness section, I show that my results are not driven by direct or list candidates only.
} 
Table 5 in the appendix shows correlations of some key variables and thereby lends support to my conjecture concerning the party list position as a proxy for individual productivity. One can see that outside earnings are negatively related to parliamentary effort as expected. More interesting though, a better position on the party list is associated with higher outside earnings and higher effort in parliament at the same time. Not controlling for individual skill of the deputy in form of her position on the party list could therefore lead to a biased estimate of the effect of outside earnings as described above.

I also construct another measure of deputy-specific skill or smartness that makes use of a special feature of the two-tier German electoral system. Almost all members of the Bundestag (also the ones that got elected via party lists) run for a direct mandate in one of the 299 electoral districts. Hence, for each delegate, I observe the share of first votes he gets in his constituency. Furthermore, I know the share of second votes his party obtains in the constituency in question. I can thus construct a measure, called Excess Votes, defined as the share of first votes candidate $i$ receives in his constituency minus the share of second votes the party of candidate $i$ gets in the constituency. I thus measure the trust voters put into a specific candidate net of their ideological preferences. Party affiliation is a strong signal in German politics and largely affects electoral performance of direct candidates. ${ }^{19}$ If a candidate manages to obtain significantly more first votes than what one would have expected given the second votes his party received, voters from other ideological backgrounds must have seen some quality in the candidate. Excess Votes thus measures the skill of the candidate as seen by the voters.

One issue remains when constructing this variable. In most electoral districts only the candidates from the two major parties (CDU and SPD) have a real chance of winning the direct mandate. People favoring one of the smaller

\footnotetext{
${ }^{19}$ As an example, Wolfgang Neskovic (DIE LINKE) won the direct mandate in the district Cottbus-Spree-Neiße as a candidate of the left party in 2009. After some innerparty conflicts, he dropped out of his parliamentary group and ran as an independent direct candidate in the 2013 election. He only managed to obtain 8.1 percent of first votes - more than 20 percentage points less than he got in the previous election where he was still affiliated with his party.
} 
parties often use their first vote to strategically support the candidate of the bigger party that is ideologically close to them. This leads to the fact that Excess Votes is systematically larger for SPD and CDU candidates because they "borrow" votes from supporters of the smaller parties GRUENE and FDP, respectively. To account for this, I standardize Excess Votes by party, such that I have a distribution of the variable that is centered around zero with a variance of one for each party. The distributions of raw excess votes can be found in Figure 2 in the appendix, while the standardized excess votes can be found in Figure 3, also in the appendix. In my analysis, I use the standardized excess votes as a proxy for deputy ability.

The vector of control variables $X$ contains, along with position on party list and excess votes, other politician-specific covariates that have to be included into the model to make the ceteris paribus assumption more likely, i.e. to compare only similar MPs with each other. To this end, $X$ contains gender, age, age squared, a dummy indicating whether the respective legislator is member of the government coalition, an indicator whether an MP is directly elected, dummies for each federal state and 32 different occupational dummies. Furthermore, I control for the fact whether MPs have (young) children, whether they are married, and for the number of terms they have been a member of the Bundestag.

\section{Results}

I will now turn to the results of my empirical analysis. In the spirit of Equation 1, Table 2 shows coefficients of regressions ${ }^{20}$ estimating the effect of outside earnings on several measures of inner-parliamentary effort. For better readability and interpretability, I directly report marginal effects at the means of all variables. ${ }^{21}$ Heteroscedasticity-robust standard errors are in

\footnotetext{
${ }^{20}$ I estimate negative binomial regressions for speeches, oral contributions, interpellations and group initiatives. For attendance, however, I employ a tobit specification to account for the fact that the attendance rate cannot surpass 100 percent.

${ }^{21}$ I also calculated average marginal effects and the findings were qualitatively and quantitatively similar. Additionally, I ran normal OLS regressions as a robustness check and
} 
parentheses. The number of observations is smaller than 652 because I miss data on age, party list position and profession for some of the delegates.

Specification (1) presents estimates of the effect of outside earnings (measured in thousands) on attendance during roll call votes. With a highly significant coefficient of -0.027 , a one standard deviation increase in ancillary income $(+111000$ Euro) reduces attendance during roll call votes by roughly three percentage points, corresponding to one third of a standard deviation in this variable. This suggests that time constraints play an important role: Representatives with more side activities spend less time in parliament, controlling for a wide range of observable characteristics.

However, one can argue that time spent in the assembly is not a good performance indicator for MPs, since it does not capture how they have used their time. More important proxies for effort in parliament are measurable activities that belong to the duties and available instruments of representatives. One of these variables is the number of speeches held in the assembly during the legislative term. This variable - varying between 0 and 140 - is taken as the dependent variable in specification (2). Again, outside earnings significantly affect this measure in the expected direction: An additional standard deviation of ancillary income is estimated to lead to 4.22 fewer speeches per legislative term. Specification (3) finds similar results for oral contributions during debate. The same holds for minor interpellations in column (4), where the point estimate is almost an order of magnitude larger as in the previous specifications. This is however due to the fact that the variable Interpellations varies between 0 and 957 and has thus a wider range than the other dependent variables. Finally, I also observe a negative effect of outside income on group initiatives. Here, one additional standard deviation in outside income reduces the number of group initiatives an MP is part of by roughly 23, corresponding to one fourth of a standard deviation in this variable. To sum up, outside earnings are negatively associated with all measures for parliamentary activity, and this effect is highly significant

the results did not change much. To save space, I do not report them here. They are, however, available upon request. 
Table 2: Main Results

\begin{tabular}{|c|c|c|c|c|c|}
\hline & $\begin{array}{c}(1) \\
\text { Attendance Rate }\end{array}$ & $\begin{array}{c}(2) \\
\text { Speeches }\end{array}$ & $\begin{array}{c}(3) \\
\text { Oral Contributions }\end{array}$ & $\begin{array}{c}(4) \\
\text { Interpellations }\end{array}$ & $\begin{array}{c}(5) \\
\text { Group Initiatives }\end{array}$ \\
\hline Outside Earnings & $\begin{array}{c}-0.027^{* * *} \\
(0.004)\end{array}$ & $\begin{array}{c}-0.038^{* * *} \\
(0.008)\end{array}$ & $\begin{array}{c}-0.017^{* * *} \\
(0.003)\end{array}$ & $\begin{array}{c}-0.129^{* * *} \\
(0.022)\end{array}$ & $\begin{array}{c}-0.210^{* * *} \\
(0.024)\end{array}$ \\
\hline Female & $\begin{array}{l}-0.358 \\
(1.220)\end{array}$ & $\begin{array}{l}-0.903 \\
(1.837)\end{array}$ & $\begin{array}{c}-2.317^{* * *} \\
(0.744)\end{array}$ & $\begin{array}{c}1.108 \\
(4.110)\end{array}$ & $\begin{array}{c}4.022 \\
(4.026)\end{array}$ \\
\hline Government Coalition & $\begin{array}{c}9.389^{* * *} \\
(1.143)\end{array}$ & $\begin{array}{l}-2.939^{*} \\
(1.694)\end{array}$ & $\begin{array}{c}-6.049^{* * *} \\
(0.725)\end{array}$ & $\begin{array}{c}-97.577^{* * *} \\
(6.156)\end{array}$ & $\begin{array}{c}-88.400^{* * *} \\
(4.794)\end{array}$ \\
\hline Age & $\begin{array}{c}1.297^{* * *} \\
(0.485)\end{array}$ & $\begin{array}{l}-0.116 \\
(0.838)\end{array}$ & $\begin{array}{l}0.554^{*} \\
(0.312)\end{array}$ & $\begin{array}{l}-1.046 \\
(2.352)\end{array}$ & $\begin{array}{c}1.031 \\
(1.830)\end{array}$ \\
\hline Age Squared & $\begin{array}{c}-0.014^{* * *} \\
(0.005)\end{array}$ & $\begin{array}{l}-0.001 \\
(0.008)\end{array}$ & $\begin{array}{c}-0.006^{* *} \\
(0.003)\end{array}$ & $\begin{array}{c}0.013 \\
(0.025)\end{array}$ & $\begin{array}{l}-0.007 \\
(0.019)\end{array}$ \\
\hline Married & $\begin{array}{c}-3.124^{* *} \\
(1.294)\end{array}$ & $\begin{array}{l}-1.254 \\
(1.919)\end{array}$ & $\begin{array}{c}-2.116^{* * *} \\
(0.715)\end{array}$ & $\begin{array}{c}3.055 \\
(4.288)\end{array}$ & $\begin{array}{l}-4.515 \\
(4.530)\end{array}$ \\
\hline Directly Elected & $\begin{array}{l}-0.510 \\
(1.176)\end{array}$ & $\begin{array}{c}-6.204^{* * *} \\
(2.062)\end{array}$ & $\begin{array}{c}-2.915^{* * *} \\
(0.811)\end{array}$ & $\begin{array}{c}11.176^{* *} \\
(5.429)\end{array}$ & $\begin{array}{l}-3.335 \\
(5.239)\end{array}$ \\
\hline Second Term & $\begin{array}{l}-1.662 \\
(1.508)\end{array}$ & $\begin{array}{c}0.502 \\
(2.418)\end{array}$ & $\begin{array}{c}1.336 \\
(0.926)\end{array}$ & $\begin{array}{l}9.911^{*} \\
(5.822)\end{array}$ & $\begin{array}{c}1.874 \\
(5.624)\end{array}$ \\
\hline Third Term & $\begin{array}{l}-0.253 \\
(1.633)\end{array}$ & $\begin{array}{l}1.444 \\
(2.566)\end{array}$ & $\begin{array}{l}2.369^{* *} \\
(1.043)\end{array}$ & $\begin{array}{c}3.068 \\
(6.033)\end{array}$ & $\begin{array}{l}-3.206 \\
(5.742)\end{array}$ \\
\hline more than 4 Terms & $\begin{array}{l}-0.521 \\
(1.528)\end{array}$ & $\begin{array}{l}-3.736 \\
(2.725)\end{array}$ & $\begin{array}{c}0.543 \\
(1.083)\end{array}$ & $\begin{array}{l}-3.045 \\
(5.774)\end{array}$ & $\begin{array}{c}-17.310^{* * *} \\
(5.853)\end{array}$ \\
\hline Young Children & $\begin{array}{l}1.801 \\
(2.293)\end{array}$ & $\begin{array}{c}2.694 \\
(4.691)\end{array}$ & $\begin{array}{c}2.278 \\
(1.733)\end{array}$ & $\begin{array}{c}2.538 \\
(9.897)\end{array}$ & $\begin{array}{c}6.000 \\
(11.159)\end{array}$ \\
\hline Teen Children & $\begin{array}{l}-0.271 \\
(1.676)\end{array}$ & $\begin{array}{l}-1.771 \\
(2.526)\end{array}$ & $\begin{array}{c}1.525 \\
(0.991)\end{array}$ & $\begin{array}{l}-2.939 \\
(6.231)\end{array}$ & $\begin{array}{c}1.474 \\
(5.675)\end{array}$ \\
\hline Adult Children & $\begin{array}{c}0.485 \\
(1.495)\end{array}$ & $\begin{array}{l}-2.262 \\
(2.413)\end{array}$ & $\begin{array}{c}0.637 \\
(0.918)\end{array}$ & $\begin{array}{l}-3.466 \\
(5.269)\end{array}$ & $\begin{array}{l}-5.913 \\
(6.411)\end{array}$ \\
\hline Female*(Young Children) & $\begin{array}{c}-10.875^{* * *} \\
(3.262)\end{array}$ & $\begin{array}{l}-7.203 \\
(6.332)\end{array}$ & $\begin{array}{l}-1.586 \\
(2.142)\end{array}$ & $\begin{array}{c}-4.977 \\
(12.039)\end{array}$ & $\begin{array}{l}-12.653 \\
(13.192)\end{array}$ \\
\hline Excess Votes & $\begin{array}{c}-1.237^{* * *} \\
(0.470)\end{array}$ & $\begin{array}{l}1.306^{*} \\
(0.783)\end{array}$ & $\begin{array}{c}0.366 \\
(0.291)\end{array}$ & $\begin{array}{l}-0.588 \\
(1.725)\end{array}$ & $\begin{array}{c}1.257 \\
(1.606)\end{array}$ \\
\hline Position on Party List & $\begin{array}{l}-0.049 \\
(0.065)\end{array}$ & $\begin{array}{c}0.020 \\
(0.096)\end{array}$ & $\begin{array}{c}0.125^{* * *} \\
(0.045)\end{array}$ & $\begin{array}{c}0.774^{* * *} \\
(0.210)\end{array}$ & $\begin{array}{c}0.740^{* * *} \\
(0.218)\end{array}$ \\
\hline State Dummies & yes & yes & yes & yes & yes \\
\hline Occupational Dummies & yes & yes & yes & yes & yes \\
\hline $\mathrm{N}$ & 491 & 496 & 496 & 496 & 496 \\
\hline Pseudo $R^{2}$ & 0.06 & 0.04 & 0.09 & 0.10 & 0.12 \\
\hline Log-Likelihood & -1516.07 & -2056.53 & -1523.28 & -2218.26 & -2397.77 \\
\hline
\end{tabular}

across all specifications.

This result informs and validates existing studies (Bernecker, 2013; Besley and Larcinese, 2011; Fisman, Harmon, Kamenica, and Munk, 2012; Gagliar- 
ducci, Nannicini, and Naticchioni, 2010) that employ only attendance rates as a proxy for parliamentary effort. By demonstrating that outcomes for other activities in parliament are similar to attendance rate results, I show that studies relying exclusively on attendance rates do not make a mistake. This is reassuring and surprising at the same time, as the correlation between attendance and the other activity variables is not very high (see also Table 5 in the appendix).

A look at the control variables also reveals some interesting insights. All specifications control for the state of provenance of the delegate. Furthermore, I control for profession and educational attainment by including 32 occupational dummies into the model. Gender does not seem to affect parliamentary activity, apart from the fact that women tend to make fewer oral contributions than men. The age pattern for parliamentary activity seems to be inverse U-shaped, at least significantly so for attendance and oral contributions. Put differently, middle agers are the most active parliament members, while young and old MPs tend to make fewer contributions. The point estimates of the quadratic specification here imply that both the peak attendance rate and the maximum or oral contributions are reached at age 46 . This confirms findings for the EU Parliament (Mocan and Altindag, 2013), where age also exhibits an inverse U-shaped effect on attendance rates.

An interesting observation is that members of the government coalition show less activity in parliament despite being present more often than their colleagues from the opposition, as can be seen from the positive coefficient of Government Coalition in column (1) and its negative coefficient in all other columns. This behavior may partly reflect their roles: On the one hand, members of the government coalition cannot afford to miss important roll call votes since their majority has to be defended in parliament. Therefore, they have lower absenteeism rates. On the other hand, instruments like speeches and oral contributions are more attractive for opposition parties and therefore used to a lesser extent by government party deputies. Interpellations and group initiatives are almost exclusively used by the opposition; hence the large negative coefficients for the government coalition dummy in 
specifications (4) and (5).

Family background and parenthood have important implications for working hours. Hence, one could suppose that parliamentary activity is affected once (especially young) children are part of an MP's household. Unfortunately, I only know the number of children each delegate has (if any), but not their age. However, I proxy the childrens' age by the age of their parents. Therefore, the dummy variable Young Children equals one if an MP indicates to have children and is younger than 40 years old, Teen Children captures parent MPs aged between 40 and 50 and Adult Children is an indicator for parents older than 50 years. I find no significant effect on parliamentary effort in any direction for all of these variables. However, having young children seems to significantly affect the attendance rate of female legislators, as the coefficient of the interaction Female*(Young Children) shows. These young mothers have an almost 11 percentage point lower attendance rate than male MPs with young children. The effect on the other parliamentary activity variables is also negative, but imprecisely estimated. This may be due to the fact that there are only 15 young mothers in the sample. Married members of parliament tend to display fewer activity, at least significantly so in terms of attendance and oral contributions. This could be a hint that leisure time is more valuable for this group.

Directly elected MPs hold significantly fewer speeches and make less oral contributions. However, they accumulate on average 11 interpellations more than their list-elected counterparts. These findings are consistent with the different incentives direct candidates face: To ensure reelection, these MPs might place a higher weight on providing constituency services than on innerparliamentary activity. However, a way of bringing constituents' concerns into parliament is via interpellations, hence the positive coefficient on this variable. To control for seniority effects that may affect participation in parliamentary life, I include dummy variables indicating the number of terms served in the legislature into the model. Being in the first term serves as the base category. I find no systematic effects of the number of terms served on parliamentary activity. 
Finally, let us turn to the variables that are supposed to proxy for deputyspecific differences in ability, Excess Votes and Position on Party List. Excess Votes is positively associated with speeches, as expected. However, the effect is insignificant in columns three to five and even displays the wrong sign for attendance. Here, Excess Votes may be endogenous due to reverse causality concerns: MPs with lots of excess votes often face relatively little electoral competition and can be almost sure to be reelected in the next election. Therefore, they can take the liberty of not showing up all the time in parliament. This may confound the effect of "skill" on attendance and the other outcome variables. ${ }^{22}$

Position on Party List gives more promising results. For this measure, I expected positive effects on all dependent variables. This turns out to be true for oral contributions, interpellations and group initiatives. Moving up one standard deviation in list position, one can observe roughly 9 additional interpellations and group initiatives, for example. The coefficients in the two remaining models are relatively small and insignificant. Nevertheless, if I leave out Excess Votes and Position on Party List and rerun the regressions, the effect of outside earnings on inner-parliamentary effort is smaller and biased towards zero, especially in models (3), (4) and (5), where Position on Party List is highly significant. This empirically confirms expectations concerning an "ability bias" from my theoretical reasoning in Section 5.

Note that I do not claim any causality as regards the effect of outside earnings on effort in parliament. Since I have only cross-sectional data, I cannot control for unobserved heterogeneity that could potentially bias my results. I have tried to take unobserved skills of legislators into account by taking up the proxies mentioned above. Nevertheless, note that any remaining bias due to unmeasured ability differentials would work against me, as it pulls the effect closer to zero. Since I still find a negative and highly significant effect, the true estimate could be even larger in absolute terms. My point estimate should thus be seen as a lower bound of the true effect.

\footnotetext{
${ }^{22}$ The problem of an equilibrium relationship between electoral competition and attendance is also mentioned in Bernecker (2013).
} 


\section{Robustness Checks}

As mentioned in Section 3, the reporting of ancillary income is not in exact amounts of Euro, but rather in three different (and broad) categories. One could thus wonder what happens if outside income is calculated using different assumptions as regards the counting of the various categories. Table 6 in the appendix shows how my main explanatory variable changes if I count income differently. Thereby, the variable Medium Earnings is obtained by taking the midpoints of categories 1 and 2 (i.e. 2250 and 5250 Euro) and counting a category 3 reporting as 10000 Euro. High Earnings is constructed by taking the upper bounds of the first two categories and counting the third category as 15000 Euro. Consequently, the maximum income earned increases from 752000 to 1612000 Euro. Note that these are arbitrary choices. However, one benchmark is available. Candidate for chancellor Peer Steinbrück revealed all his outside income accurate to the Euro after public pressure in Germany had gotten too high. We know since then that he earned exactly 1.25 million Euro with activities besides his mandate. ${ }^{23}$ In my calculations, which are based on the assumptions above, Steinbrück had Minimum Earnings of 724000 Euro, Medium Earnings of 1037250 Euro and High Earnings of 1554500 Euro. Hence, for this particular MP, counting earnings not in the most conservative way is actually closer to the truth.

Therefore, it is interesting to see whether regression results change when I use medium or high earnings as an explanatory variable. ${ }^{24}$ The results can be found in Table 3, where each cell corresponds to a separate regression with all control variables from the baseline specification. While the first row simply reproduces the results from Table 2, rows two and three show

\footnotetext{
${ }^{23}$ http://www.zeit.de/politik/deutschland/2012-10/steinbrueck-nebeneinkuenftehonorar, accessed on November $18^{\text {th }}, 2013$

${ }^{24}$ Please note that the different calculation does not correspond to simply multiplying my explanatory variable with a fixed factor. Since a given outside income can be achieved via various combinations of Level 1,2 or 3 reportings, the different counting of the categories can actually make a difference. Hence, when I sort the MPs according to their Minimum Earnings, this can produce a different rank ordering than when I sort them along the lines of Medium Earnings or High Earnings. As an example, see Table 7 in the appendix, which depicts the top earners in terms of the three definitions of outside income.
} 
Table 3: Effects of Differently Counted Outside Income

\begin{tabular}{lccccc}
\hline \hline & $(1)$ & $(2)$ & $(3)$ & $(4)$ & $(5)$ \\
Outside Earnings: & Attendance Rate & Speeches & Oral Contributions & Interpellations & Group Initiatives \\
\hline Minimum Earnings & $-0.027^{* * *}$ & $-0.038^{* * *}$ & $-0.017^{* * *}$ & $-0.129^{* * *}$ & $-0.210^{* * *}$ \\
& $(0.004)$ & $(0.008)$ & $(0.003)$ & $(0.022)$ & $(0.024)$ \\
& {$[-0.31]$} & {$[-0.20]$} & {$[-0.16]$} & {$[-0.10]$} & {$[-0.24]$} \\
Medium Earnings & $-0.013^{* * *}$ & $-0.023^{* * *}$ & $-0.007^{* * *}$ & $-0.058^{* * *}$ & $-0.070^{* * *}$ \\
& $(0.003)$ & $(0.005)$ & $(0.002)$ & $(0.014)$ & $(0.018)$ \\
High Earnings & {$[-0.25]$} & {$[-0.21]$} & {$[-0.11]$} & {$[-0.08]$} & {$[-0.13]$} \\
& $-0.009^{* * *}$ & $-0.015^{* * *}$ & $-0.004^{* * *}$ & $-0.039^{* * *}$ & $-0.047^{* * *}$ \\
& $(0.002)$ & $(0.003)$ & $(0.001)$ & $(0.009)$ & $(0.012)$ \\
& {$[-0.26]$} & {$[-0.21]$} & {$[-0.09]$} & {$[-0.08]$} & {$[-0.13]$} \\
\hline
\end{tabular}

Notes: The table directly reports marginal effects at the means of all variables. Standard errors in parentheses. Standard deviation elasticities in square brackets. Significance Levels: ${ }^{*} \mathrm{p}<0.10,{ }^{* *} \mathrm{p}<0.05,{ }^{* * *} \mathrm{p}<0.01$.

that the effect of outside earnings on inner-parliamentary effort is also significantly negative and robust to how these outside earnings are calculated. The estimated coefficients naturally become smaller because the spread of the explanatory variable gets larger with a less conservative calculation of ancillary income. To compare coefficients across specifications, I report standard deviation elasticities in square brackets. For example, a one standard deviation increase in medium earnings leads to a 0.25 standard deviation decrease in attendance. The effects seem to be of similar size for the various definitions of outside earnings, with an exception for group initiatives, where the elasticity is smaller for the two higher earnings definitions in comparison to the base definition.

As mentioned beforehand, only one third of all MPs earn money with outside activities. Hence, my main explanatory variable Outside Earnings has many structural zeros. To show that my results are unaffected by this, I estimated the model again using only representatives with positive ancillary income. This reduces the number of usable observations from 652 to 214 . The results can be found in Panel 1 of Table 4. Outside Earnings retains its significance in all specifications and the size of the effect is in the same ballpark for the attendance rate, speeches and oral contributions. For interpellations and group initiatives, the coefficients are smaller but still highly significant. I conclude that the many delegates with zero outside earnings do not bias my 
qualitative results.

Table 4: Results for important subgroups

\begin{tabular}{|c|c|c|c|c|c|}
\hline & $\begin{array}{c}(1) \\
\text { Attendance Rate }\end{array}$ & $\begin{array}{c}(2) \\
\text { Speeches }\end{array}$ & $\begin{array}{c}(3) \\
\text { Oral Contributions }\end{array}$ & $\begin{array}{c}(4) \\
\text { Interpellations }\end{array}$ & $\begin{array}{c}(5) \\
\text { Group Initiatives }\end{array}$ \\
\hline & \multicolumn{5}{|c|}{ Panel 1: Only MPs with positive outside earnings } \\
\hline Outside Earnings & $\begin{array}{c}-0.024^{* * *} \\
(0.005)\end{array}$ & $\begin{array}{c}-0.048^{* * *} \\
(0.009)\end{array}$ & $\begin{array}{c}-0.015^{* * *} \\
(0.003)\end{array}$ & $\begin{array}{c}-0.038^{* * *} \\
(0.006)\end{array}$ & $\begin{array}{c}-0.089^{* * *} \\
(0.014)\end{array}$ \\
\hline $\mathrm{N}$ & 171 & 171 & 171 & 171 & 171 \\
\hline Pseudo $\mathrm{R}^{2}$ & 0.09 & 0.06 & 0.15 & 0.15 & 0.16 \\
\hline \multirow[t]{2}{*}{ Log-Likelihood } & -535.01 & -686.28 & -460.05 & -553.83 & -684.76 \\
\hline & \multicolumn{5}{|c|}{ Panel 2: Only party list MPs } \\
\hline Outside Earnings & $\begin{array}{c}-0.019^{* * *} \\
(0.005)\end{array}$ & $\begin{array}{c}-0.077^{* * *} \\
(0.014)\end{array}$ & $\begin{array}{c}-0.026^{* * *} \\
(0.006)\end{array}$ & $\begin{array}{c}-0.193^{* * *} \\
(0.034)\end{array}$ & $\begin{array}{c}-0.328^{* * *} \\
(0.044)\end{array}$ \\
\hline $\mathrm{N}$ & 279 & 284 & 284 & 284 & 284 \\
\hline Pseudo $\mathrm{R}^{2}$ & 0.07 & 0.05 & 0.08 & 0.13 & 0.11 \\
\hline \multirow[t]{2}{*}{ Log-Likelihood } & -861.18 & -1190.79 & -935.03 & -1374.50 & -1455.86 \\
\hline & \multicolumn{5}{|c|}{ Panel 3: Only directly elected MPs } \\
\hline Outside Earnings & $\begin{array}{c}-0.033^{* * *} \\
(0.007)\end{array}$ & $\begin{array}{l}-0.006 \\
(0.009)\end{array}$ & $\begin{array}{c}-0.009^{* * *} \\
(0.003)\end{array}$ & $\begin{array}{c}-0.032^{* * *} \\
(0.008)\end{array}$ & $\begin{array}{c}-0.124^{* * *} \\
(0.021)\end{array}$ \\
\hline $\mathrm{N}$ & 212 & 212 & 212 & 212 & 212 \\
\hline Pseudo $\mathrm{R}^{2}$ & 0.08 & 0.04 & 0.13 & 0.12 & 0.13 \\
\hline Log-Likelihood & -621.18 & -822.16 & -549.30 & -764.07 & -911.67 \\
\hline
\end{tabular}

Notes: Standard errors in parentheses. Significance Levels: ${ }^{*} \mathrm{p}<0.10,{ }^{* *} \mathrm{p}<0.05,{ }^{* * *} \mathrm{p}<0.01$. The table directly reports marginal effects at the means of all variables.

One can also ask the question whether list-elected or directly elected representatives have different incentives as regards activity inside and outside parliament. For example, some might argue that directly elected MPs additionally need to serve their constituency and therefore suffer larger negative effects of outside earnings on inner-parliamentary activity due to binding time constraints. This is in fact what can be found when comparing the coefficients of Outside Earnings on the attendance rate during roll call votes in panels 2 and 3 in Table 4 . When following sideline activities, directly elected MPs experience higher losses in their attendance rates than list-elected MPs. However, this doesn't carry over to the other parliamentary productivity variables, where the effect is weaker and sometimes imprecisely estimated for directly elected MPs. 
As a final robustness exercise, I check whether my results are sensible to outliers. I have mentioned before that the measures for parliamentary activity have a highly skewed distribution (see also Figure 1 in the appendix). For interpellations and group initiatives, the maximum is ten or respectively six times as large as the mean. To show that these observations leave my results unaffected, I redid the main estimation, thereby dropping either the top one, top five or top ten percent of representatives who have very large counts of parliamentary activity. The results, which are available upon request, suggest that extreme values in the outcome variables are unproblematic: The coefficients of the models with outliers excluded are still highly significant and of similar size as in the model with all observations. The same holds for outliers in Outside Earnings, the main independent variable. If I exclude MPs with the highest ancillary incomes, the coefficients go somewhat down in size but retain their significance.

\section{Conclusion}

In this paper, I have shown that members of the German Bundestag who earn more money with sideline jobs beneath their mandate display significantly lower activity in parliament, be it in terms of speeches held, attendance during roll call votes or other parlimentary practices. This effect survives the inclusion of a wide array of control variables and several robustness checks for important subgroups only. Furthermore, the calculation of outside income does not seem to qualitatively affect the results. To the best of my knowledge, I am first to analyze the interplay between activity inside and outside parliament for German MPs, thereby using a novel dataset on Bundestag members from 2009-2013. I also introduced some new measures to proxy for legislator ability that make use of special institutional features of the German electoral system. Furthermore, I validate and complement existing research (Bernecker, 2013; Besley and Larcinese, 2011; Fisman, Harmon, Kamenica, and Munk, 2012; Gagliarducci, Nannicini, and Naticchioni, 2010) by looking at parliamentary performance indicators that go beyond the attendance rate. 
Some caveats are in order. First, my dependent variables are no perfect measures of inner-parliamentary effort. The attendance rate only captures time tradeoffs, but not commitment or devotion ${ }^{25}$ to the job. Other indicators like speeches or interpellations are better in this respect, but simply counting them can lead to false positives: Staffers could have done the work or MPs might free ride on the effort of their parliamentary group by putting their name on a bill in the last minute. Therefore, my quantitative results have to be interpreted with caution and should be complemented by qualitative work. This is a promising avenue for further research.

Another limitation of my approach is that I do not link specific outside activities to specific behaviors in parliament. For example, one could screen the contents of speeches or bills brought forward by individual deputies and look if there is any connection to the agenda of outside employers. ${ }^{26}$ The most famous example of this behavior is probably former chancellor Gerhard Schröder, who - while in office - enacted the construction of an oil pipeline through the baltic sea and later on held a profitable sideline job in the pipeline company's board of directors. ${ }^{27}$

Nevertheless, my findings bear important policy implications. First, given my results for quantitative performance indicators, a weekly limit on the hours worked outside parliament seems worth discussing. According to interview statements ${ }^{28}$ of German MPs, mandate-related work takes up to 80 hours per week. With a baseload of twice the hours of a normal fulltime job, the observed negative relationship between activity outside and inside parliament thus seems intuitive. Time caps on moonlighting could therefore limit the "losses" that parliament has to bear. Second, disclosure rules for politicians' outside earnings should be extended and refined to give

\footnotetext{
${ }^{25}$ Admittedly, these things are difficult - if not impossible - to measure.

${ }^{26}$ The technology for such quantitative text analyses is available. See for example Klüver (2009) for methods of extracting and comparing policy positions from different players in the political arena.

${ }^{27}$ http://www.spiegel.de/politik/deutschland/neuer-job-schroeder-verrubelt-seinen-ruf-a389956. html, accessed on November $18^{\text {th }}, 2013$

${ }^{28}$ http://www.mz-web.de/halle-saalekreis/arbeitszeit-der-politiker-stress-nicht-nur-beiplatzeck,20640778,23901842.html, accessed on November $18^{\text {th }}, 2013$
} 
citizens a better possibility to monitor their elected officials. The present transparency requirements give members of parliament considerable leeway in hiding income information from the public. However, this is about to change: From 2014 on, outside earnings of German MPs have to be reported in a 10-category system instead of the 3-category system currently in place. 


\section{References}

Bank, S., B. Cheffins, and M. Goergen (2009): "Dividends and politics," European Journal of Political Economy, 25(2), 208-224.

Becker, J., A. Peichl, And J. Rincke (2009): "Politicians' outside earnings and electoral competition," Public Choice, 140(3-4), 379-394.

Bernecker, A. (2013): "Do Politicians Shirk when Reelection Is Certain? Evidence from the German Parliament," Uni Mannheim Department of Economics Working Paper 13-09.

Besley, T., And V. Larcinese (2011): "Working or shirking? Expenses and attendance in the UK Parliament," Public Choice, 146(3-4), 291-317.

FAcCIO, M. (2006): "Politically connected firms," American Economic Review, 96(1), 369-386.

Fisman, R., N. A. Harmon, E. Kamenica, and I. Munk (2012): "Labor Supply of Politicians," NBER Working Paper 17726.

Gagliarducci, S., T. Nannicini, and P. Naticchioni (2010): "Moonlighting politicians," Journal of Public Economics, 94(9), 688-699.

Geys, B. (2013): "Election cycles in MPs' outside interests? The UK House of Commons, 2005-2010," Political Studies, 61(2), 462-472.

Geys, B., And K. Mause (2012a): "Are Female Legislators Different? Exploring Sex Differences in German MPs' Outside Interests," Parliamentary Affairs.

(2012b): "Delegation, Accountability \& Legislator Moonlighting: Agency Problems in Germany," German Politics, 21, 255-273.

- (2013): "Moonlighting politicians: A Survey and Research agenda," Journal of Legislative Studies, 19(1), 76-97.

Hönigsberger, H. (2013): "Die sechste Fraktion - Nebenverdiener im Deutschen Bundestag," OBS Arbeitspapier, 11. 
Jennings, C. (2011): "The good, the bad and the populist: A model of political agency with emotional voters," European Journal of Political Economy, 27(4), 611-624.

KLÜVER, H. (2009): "Measuring interest group influence using quantitative text analysis," European Union Politics, 10(4), 535-549.

Long, J. S., And J. Freese (2006): "Regression models for categorical dependent variables using Stata," Stata Press Books.

Mause, K. (2009): "Nebentätige Bundestagsabgeordnete: Was offenbaren die Veröffentlichungspflichten?," Perspektiven der Wirtschaftspolitik, 10(2), 146-174.

Mocan, N., and D. T. Altindag (2013): "Salaries and Work Effort: An Analysis of the European Union Parliamentarians," The Economic Journal, doi: 10.1111/ecoj.12056.

Niessen, A., And S. Ruenzi (2010): "Political connectedness and firm performance: Evidence from Germany," German Economic Review, 11(4), 441-464.

Piolatto, A. (2011): "Plurality versus proportional electoral rule: Which is most representative of voters?," European Journal of Political Economy, 27(2), 311-327. 


\section{Appendix}

Figure 1: Distribution of Outcome Variables
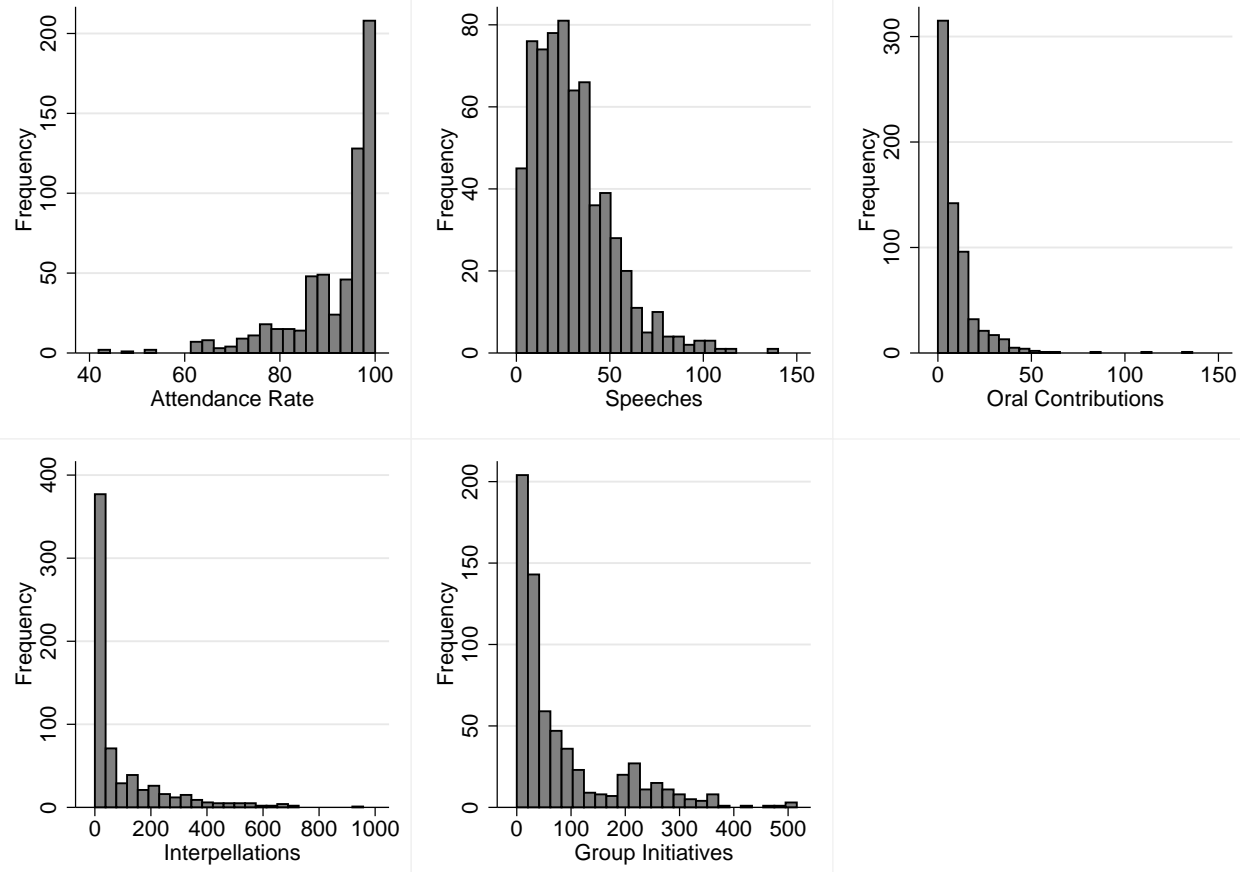

Table 5: Correlation of Key Variables

\begin{tabular}{|c|c|c|c|c|c|c|c|}
\hline Variables & Outside Earnings & Attendance Rate & Speeches & Oral Contributions & Interpellations & Group Initiatives & Position on Party List \\
\hline Outside Earnings & 1.00 & & & & & & \\
\hline Attendance Rate & -0.18 & 1.00 & & & & & \\
\hline Speeches & -0.21 & 0.16 & 1.00 & & & & \\
\hline Oral Contributions & -0.19 & 0.03 & 0.36 & 1.00 & & & \\
\hline Interpellations & -0.23 & -0.13 & 0.24 & 0.49 & 1.00 & & \\
\hline Group Initiatives & -0.28 & -0.12 & 0.30 & 0.47 & 0.83 & 1.00 & \\
\hline Position on Party List & 0.08 & -0.05 & 0.06 & 0.10 & 0.16 & 0.18 & 1.00 \\
\hline
\end{tabular}


Figure 2: Raw Excess Votes by Party
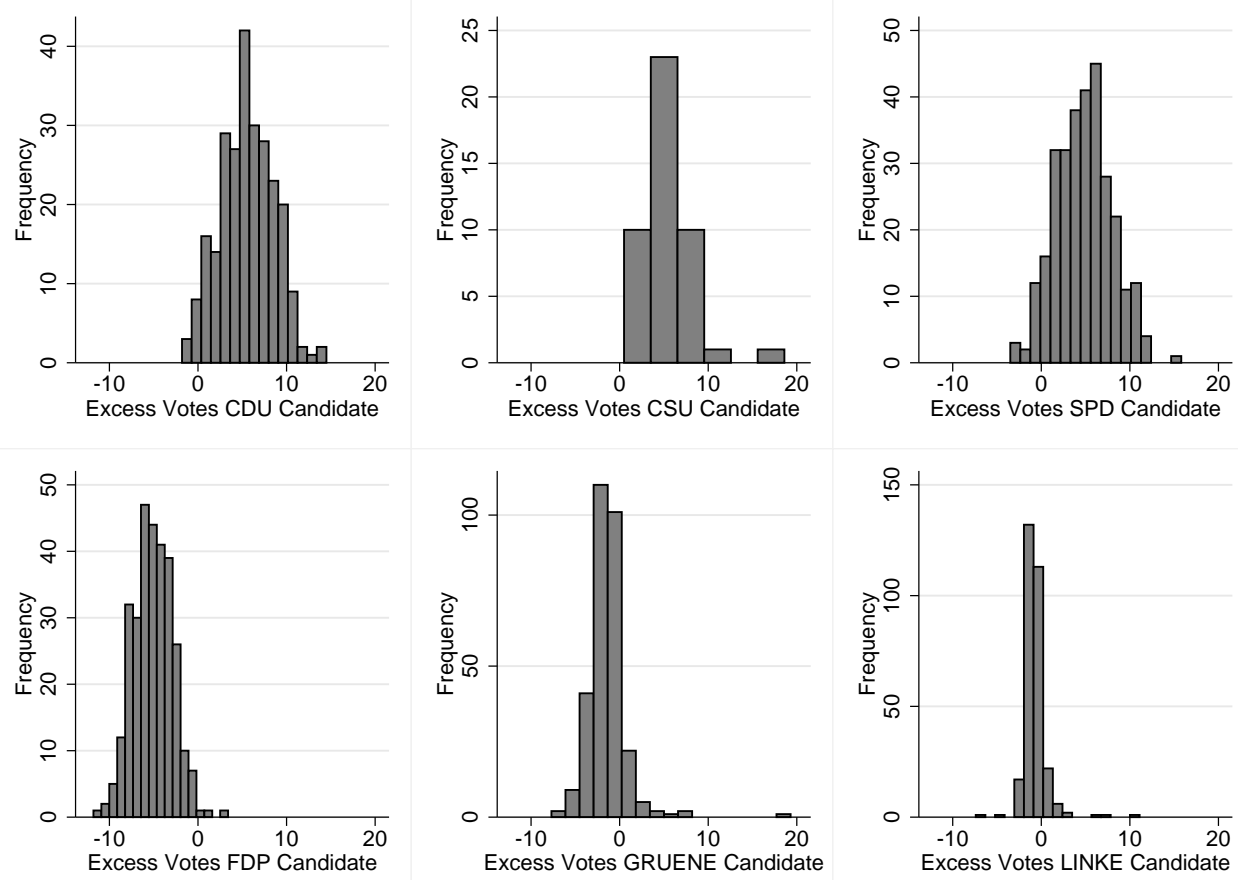

Table 6: Calculating Outside Income

\begin{tabular}{lccccc}
\hline \hline \multicolumn{1}{c}{ Variable } & Mean & Std. Dev. & Min. & Max. & N \\
\hline Minimum Earnings & 47580.17 & 111156.16 & 0 & 752484 & 652 \\
Medium Earnings & 88677.41 & 186662.82 & 0 & 1074977 & 652 \\
High Earnings & 132095.37 & 278297.9 & 0 & 1612466 & 652 \\
\hline
\end{tabular}

Table 7: MPs with Highest Outside Earnings

\begin{tabular}{|c|c|c|c|c|c|c|c|c|}
\hline Name & Party & Minimum Earnings $(€)$ & Name & Party & Medium Earnings $(€)$ & Name & Party & High Earnings $(€)$ \\
\hline 1. Michael Glos & $\mathrm{CSU}$ & 752484 & 1. Michael Brand & CDU & 1074977 & 1. Michael Brand & CDU & 1612466 \\
\hline 2. Peer Steinbrück & SPD & 724000 & 1. Michael Grosse-Brömer & $\mathrm{CDU}$ & 1074977 & 1. Michael Grosse-Brömer & $\mathrm{CDU}$ & 1612466 \\
\hline 3. Daniel Bahr & FDP & 496300 & 1. Michael Paul & CDU & 1074977 & 1. Michael Paul & $\mathrm{CDU}$ & 1612466 \\
\hline 4. Rudolf Henke & CDU & 433393 & 1. Michael Stübgen & CDU & 1074977 & 1. Michael Stübgen & CDU & 1612466 \\
\hline 5. Frank Steffel & $\mathrm{CDU}$ & 397333 & 1. Michael Glos & $\mathrm{CSU}$ & 1074977 & 1. Michael Glos & $\mathrm{CSU}$ & 1612466 \\
\hline 6. Ilse Aigner & CSU & 376242 & 6. Peer Steinbrück & SPD & 1037250 & 6. Peer Steinbrück & SPD & 1554500 \\
\hline 7. Peter Bleser & CDU & 365833 & 7. Daniel Bahr & FDP & 709000 & 7. Daniel Bahr & FDP & 1063500 \\
\hline 8. Max Lehmer & $\mathrm{CSU}$ & 358633 & 8. Rudolf Henke & $\mathrm{CDU}$ & 619132 & 8. Rudolf Henke & CDU & 928699 \\
\hline
\end{tabular}


Figure 3: Standardized Excess Votes by Party
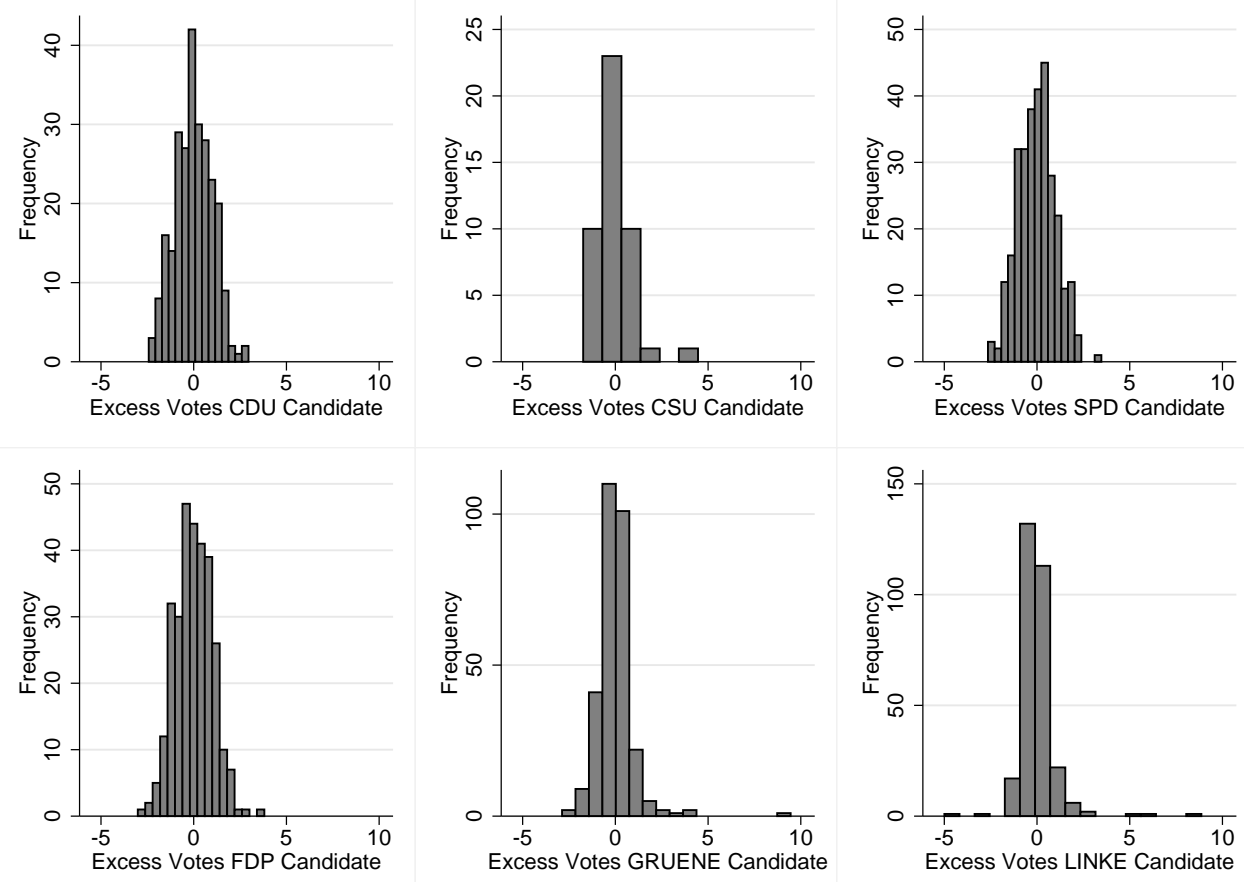